Innlegg på inntil 400 ord lastes opp i http://mc.manuscriptcentral.com/tidsskriftet.

Redaksjonen forbeholder seg retten til å foreta redaksjonelle endringer.

Forfattere av vitenskapelige artikler har automatisk tilsvarsrett (jf. Vancouver-gruppens regler).

\section{Bedriftshelsetjeneste og IA-avtalen}

I Tidsskriftet nr. 8/2010 argumenterer M. Mathisen for at den foreslåtte forandringen i dialogmøter kommer til å binde opp altfor mange legeårsverk (1), legeårsverk som kunne ha vært brukt til pasienter som trenger legehjelp. Jeg er enig i det. I forsøket på å få bukt med sykefraværet settes det etter min mening i gang mange tiltak som ikke blir evaluert på effektivitet $i$ forhold til ressursbruk og resultat. Dette gjelder ikke bare tiden fastlegen skal bruke, men også andre tiltak. Det satses mye penger på arbeidslivssentrene, men vet vi noe om resultatet? Og hva med tiltak innenfor Raskere tilbake? Arbeidsrettet rehabilitering er utvilsomt et bra tiltak i mange tilfeller, men har vi oversikt over om personer faktisk kommer raskere tilbake etter et arbeidsrettet rehabiliteringsopphold? Uansett kommer man inn ganske sent i fraværsforløpet. Kanskje det finnes andre metoder som kan settes inn tidligere, som er mindre ressurskrevende og som har likt resultat? Bedriftshelsetjenesten har en helt annen mulighet enn fastlegene til å jobbe forebyggende med inkluderende arbeidsliv (IA). En slik tilnærming er gjort i intervensjonsforsøk både i Finland (2) og i Nederland (3), med en fraværsreduksjon på om lag $35 \%$ sammenliknet med kontrollgruppen.

Mathisen nevner ikke at ifølge arbeidsmiljøloven og trygdeloven skal også bedriftshelsetjeneste være representert på dialogmøtet. Før 1.1. 2010 var nesten $60 \%$ av alle arbeidstakere tilknyttet en bedriftshelsetjeneste. Nå er store deler av kommunal virksomhet (undervisning/helsesosial) også pålagt å ha bedriftshelsetjeneste. Hvorfor ikke satse mer på denne tjenesten? Der er det helsepersonell som kjenner bedriften og likevel jobber i en fri og uavhengig stilling. Godkjenningsordningen som er innført for bedriftshelsetjenesten (4) vil dessuten bidra til å sikre at kvaliteten på tjenestene blir bedre.

Jeg savner dialog om rollefordeling og mer fornuftig bruk av ressurser i fraværsarbeidet. Hvem kan ta tak i det?

\section{Marijke Engbers}

Modum

Litteratur
1. Mathisen M. Feilslått forslag om IA-avtalen. Tidsskr Nor Legeforen 2010; 130: 818
2. Taimela S, Malmivaara A, Justen $\mathrm{S}$ et al. The effectiveness of two occupational health intervention programmes in reducing sickness absence among employees at risk. Two randomised controlled trials. Occup Environ Med 2008; 65: 236-41. 3. Kant IJ, Jansen N, van Amelsvoort L et al. Structured early consultation with the occupational physician reduces sickness absence among office workers at high risk for long-term sickness absence: a randomized controlled trial. J Occup Rehabil 2008; 18: 79-86

4. Forskrift om virksomheters bruk av godkjent bedriftshelsetjeneste og godkjenning av bedriftshelsetejeneste. Oslo: Arbeids- og inkluderingsdepartementet, 2009.

\section{Zopiklon og krampeanfall}

Benzodiazepiner og benzodiazepinliknende medikamenter skrives sannsynligvis ut for ofte til personer som har rusmiddelproblemer, skriver Helge Waal \& Jørgen G. Bramness i Tidsskriftet nr. 6/10 (1). Zopiklon er det mest brukte sovemidlet i Norge. Få betrakter medikamentet som avhengighetsskapende. Det fremgår heller ikke av Felleskatalogen at krampeanfall kan oppstå etter seponering. Vi vil belyse disse problemstillingene med en sykehistorie fra egen praksis.

En mann i 20-30-årsalderen kom for første gang til avrusingsavdeling i forkant av videre psykiatrisk behandling. Han hadde tidligere hatt innleggelser med diagnosene blandingsavhengighet, affektiv lidelse og $A D / H D$. Pasienten opplyste ved innkomst at han brukte zopiklon 7,5 mg opptil 15 tabletter daglig og ingen andre faste medisiner. Han hadde aldri hatt epilepsi eller krampeanfall av annen årsak. Han avga rene urinprøver på opiater, benzodiazepiner, amfetamin og cannabis ved innkomst. I journalen var det anført misbruk av zopiklon i kombinasjon med antidepressiver og alkohol fra 2001. I 2009 var forbruket kommet opp i 200 tabletter zopiklon per uke, og man iverksatte en gradvis nedtrapping frem til innleggelsen da han brukte ca. 12 tabletter per dag.

Han var motivert for rask avvenning og fikk standard krampeprofylakse med $1200 \mathrm{mg}$ valproat daglig. Zopiklon ble seponert. Ca. 36 timer etter innkomst ble pasienten observert sengeliggende og noe fjern, men det lot seg gjøre å kommunisere med ham. Han mistet så bevisstheten, begynte å riste og ble etter hvert stiv i kroppen. Anfallet varte ca. 90 sekunder. Deretter våknet pasienten, desorientert, prøvde å reise seg, men falt ned på skulderen og dunket hodet $i$ veggen. Det var postiktal tretthet, men ikke urinavgang eller tungebitt. Etter anfallet sov pasienten i 10 timer under tilsyn. I etterkant valgte man å fortsette gradvis nedtrapping med zopiklon til null over en uke. Det kom ingen nye krampeanfall og pasienten ble utskrevet som avtalt.

I litteraturen har vi funnet to beskrivelser av krampeanfall hos zopiklonbrukere. Fra England er det et tilfelle hvor en 76 år gammel kvinne utviklet tonisk-kloniske kramper to dager etter brå seponering av zopiklon. Hun hadde brukt ni tabletter 7,5 $\mathrm{mg}$ daglig delt på tre doser i noen måneder (2). Den andre rapporten omhandlet en 36 år gammel mann som brukte $30-90 \mathrm{mg}$ zopiklon daglig. Han fikk to abstinensanfall i forbindelse med seponering av medikamentet. Denne pasienten brukte også alkohol, antidepressiver og nevroleptika (3).

Etter vår mening bør zopiklon betraktes på samme måte som benzodiazepiner når det gjelder avhengighetsutvikling og abstinens, og benyttes deretter med gradvis nedtrapping. En god artikkel står i Canadian Family Physician (4).

\section{Øistein Kristensen}

\section{Adrian Razvan Pasareanu}

Avdeling for rus og avhengighetsbehandling Sørlandet Sykehus

\section{Litteratur}

1. Waal H, Bramness JG. Benzodiazepiner til personer med rusmiddelproblemer? Tidsskr Nor Legeforen 2010; 130: 610-2.

2. Flynn A, Cox D. Dependence on zopiclone. Addiction 2006; 101: 898-900.

3. Aranko K, Henriksson M, Hublin C et al. Misuse of zopiclone and covulsiones during withdrawal. Pharmacopsychiatry 1991; 24: 138-40.

4. Cimolai N. Zopiclone - is it a pharmacological agent for abuse? Can Fam Phys, 2007; 53: 2124-9 www.cfp.ca/cgi/content/full/53/12/2124 (14.4.2010).

Pasienten har gitt samtykke til omtalen.

\section{J.G. Bramness og H. Waal svarer:}

Selv om zopiklon muligens kan ha mindre misbruksfare enn benzodiazepiner (1), binder medikamentet seg antakelig til samme sted som benzodiazepiner på $\mathrm{GABA}_{\mathrm{A}}$-reseptoren (mellom $\beta$ og $\gamma_{2}$-subenhetene av den pentamere reseptoren). Det vil derfor forekomme toleranseutvikling, noe det også gjøres oppmerksom på i teksten i Felleskatalogen. I tillegg nevnes abstinensplager. Et forbruk på 100-200 mg zopiklon per dag er 
meget høyt. Brå avslutning av slik tilførsel kan med stor sikkerhet gi store seponeringssymptomer med fare for kramper og fullt utviklet delirium. Man bør derfor, som i kasuistikken, trappe ned over noe tid.

At Kristensen \& Pasareanu bare har funnet to tidligere publikasjoner på kramper, illustrerer nødvendigheten av at man rapporterer og publiserer denne typen kasuistikker. Deres bidrag er derfor verdifullt.

\section{Jørgen G. Bramness \\ Helge Waal \\ Senter for rus- og avhengighetsforskning Universitetet i Oslo

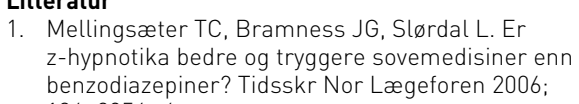

\section{Om å ri sine kjepphester}

Jeg registrerer at nevrologene Harald Schrader og Lars Jacob Stovner i Tidsskriftet nr. 5/2010 forsøker å trekke professor Per Holcks kunnskaper i tvil (1). For mange nakkeskadede er det ubegripelig at nevrologene nærmest har tiltatt seg et monopol på sakkyndighet når det gjelder alle typer nakkeskader. Jeg har ingen problemer med å se at de skal ha en slik funksjon i forhold til sykdom og infeksjoner eller ved direkte skade på nervesystemet. En stor del av nakkeskadene dreier seg imidlertid ikke om dette. Det gjelder skader på ledd og leddbånd som hører inn under muskelog skjelettsystemet. Det finnes intet i fagplanene for nevrologi som dekker dette.

Siste generalplan for Norsk nevrologisk forening fra 2006 sier heller ikke noe om denne type problemer (2). Ledd- og leddbåndsskader er kort og greit ikke nevrologenes bord. I tilfeller der det er mistanke om alvorlige leddbåndsskader skal nevrologene henvise pasientene til spesialister på muskelog skjelettsystemet. Det har de ikke gjort. Nevrologene har funnet det mer passende å skyve denne pasientgruppen over i fagområdet psykologi/psykiatri. Schrader og Stovner har vært blant de fremste talsmennene for dette gjennom forskning basert på en såkalt biopsykososial tilnærming (3).

De trekker også en ytterliggående konsekvens av sin psykologiske tilnærming ved å hevde at nakkeslengskadede ikke bør få skadeerstatning. Om dette skriver de to: «Fordelen med en konsekvent avvisning av erstatningskrav vil være at det sendes sterke signaler om den gode prognosen vanlig nakkesleng har» (1).

Deres forsøk på å trekke professor Holcks kompetanse i tvil stimulerer i første omgang smilebåndet. Ved nærmere ettertanke finner jeg det alvorlig at disse to får gjøre seg til talsmenn for nevrologi i Norge. Jeg etterlyser kunnskapsrike, skrivekyndige nevrologer som kan gi et bedre bilde av problematikken rundt nakkeskader i norsk helsevesen.

\section{Thorleif Næss \\ Bergen \\ Litteratur \\ 1. Schrader H, Stovner LJ. Feilaktig om bløtdelsska- der etter nakkesleng. Tidsskr Nor Legeforen 2010 130: 473 . \\ 2. Generalplan for nevrologi. Oslo: Norsk nevrologisk forening, 2006. www legeforeningen no/id/ 59859.c0 (18.5.2010) \\ 3. Schrader H, Stovner LJ. Kronisk nakkeslengsyn- drom - en oversikt. Tidsskr Nor Lægeforen 2002: 122: $1296-9$.}

\section{En estetisk nedtur}

Jeg tør påstå at jeg aldri har sett en styggere forside enn den som ble presentert i Tidsskriftet nr. 9/2010. Dette var rett og slett så estetisk vemmelig at morgenkaffen satte seg i vranghalsen. Over hele forsiden veltet rumpesprekk og rumpehull seg ekshibisjonistisk opp på frokostbordet $\mathrm{i}$ et zoomet nærbilde. Rumpa var dessuten nærmest gjengrodd av hår - noe jeg må medgi at jeg ikke har den store sansen for. Men prikken over i-en var den rødlige, væskende og pussbefengte «tvillingen» øverst i rumpesprekken som lyste mot deg. Naturligvis, for ellers hadde ikke dette hatt noen mening $i$ et medisinsk tidsskrift. Fargevalget for øvrig, blekrosa og brunt, bidro definitivt ikke til å gi denne forsiden et helt nødvendig løft. Tvert imot!

Tilbakemelding til redaksjonen: Nummeret ble kommentert med latter og hoderisting av kollegene på jobben. For egen del forsvant all morgenappetitt som dugg for solen, og jeg rakk så vidt å bla igjennom annonsene før min kone ryddet Tidsskriftet bort samme dag. Da jeg spurte hvor det var blitt av, sa hun at det hadde havnet i papirdunken.

\section{Arne Borthne}

Akershus universitetssykehus

\section{En myte at obduksjoner gir direkte klinisk nytte}

I kronikken min om obduksjoner i Tidsskriftet nr. 7/2010 konkluderte jeg med at det - på tross av det patologer stadig hevderikke er grunn til å øke frekvensen av ikkerettslige obduksjoner (1). I nr. 11/2010 var det innlegg fra to som begge mener at obduksjonsfrekvensen bør økes $(2,3)$.

Både Alfsen og Ellingsen \& Mæhlen fremstiller et romantisk scenario der obduksjoner er en viktig kunnskapskilde for klinikere. Et hovedpoeng med kronikken var nettopp å vise at den direkte kliniske nytten av obduksjoner er en myte. Ingen har vist at høy obduksjonsfrekvens gir bedre diagnostikk og behandling. Dessuten er tallrike obduksjonsserier allerede publisert. Klinikere bør heller studere disse.

Alfsen mener jeg hevder at de ikke-rettslige obduksjonene er til for patologenes skyld. Selvsagt mener jeg ikke det. Som det fremgår av kronikken, er patologenes kunnskapservervelse og -vedlikehold kun én av flere årsaker til at man bør obdusere. Alfsen anslår videre at en obduksjon kun koster rundt 1500 kroner. Men hennes regnestykke blir feil. Man må huske at et helt system, blant annet mange stillinger, på en patologisk avdeling er basert på dagens obduksjonsfrekvens. Da blir selvsagt 1500 kroner et altfor lavt estimat.

Som sagt i kronikken, mener jeg at et ønske fra pårørende om obduksjon bør imøtekommes, og likeledes trenger patologer obduksjoner for å erverve og vedlikeholde kunnskap. Foruten dette bør ikke-rettslige obduksjoner forbeholdes tidsbegrensede vitenskapelige studier, enten ved at «alle» obduseres i en periode, eller ved at tilfeldige personer systematisk trekkes ut til å bli obdusert. Dette vil kunne gi pekepinn om hvilke systematiske feil som gjøres i diagnostikken. Tilfeldige, ikke-systematiske obduksjoner har man derimot ikke bruk for.

Ellingsen \& Mæhlen mener at korrekte diagnoser er viktig for Dødsårsaksregisteret, og at dette også er et argument for å øke obduksjonsfrekvensen. Men man må kunne stille spørsmål ved hvor viktig en detaljert dødsårsak er for samfunnet. Hvis man for eksempel ved «mors subita» (plutselig, uventet død) gjetter at dødsfallet skyldes akutt hjerteinfarkt, vil denne diagnosen være feil i over $50 \%$ av tilfellene. Men differensialdiagnosene, som f.eks. akutt lungeemboli, akutt slag eller rumpert aortaaneurisme, har mange risikofaktorer felles med akutt hjerteinfarkt. Samfunnets profylaktiske tiltak blir hovedsakelig de samme, enten personen døde av akutt hjerteinfarkt eller av differensialdiagnosene. Trenger vi egentlig å vite hvilken kardiovaskulær sykdom vedkommende døde av - holder det ikke å si at dødsårsaken var akutt kardiovaskulær sykdom?

Som hovedregel mener jeg at respekt for den avdøde tilsier at personen skal få ligge urørt når livet har ebbet ut. Når man etter døden møter de pårørende, er justering av vitalstatistikk et for svakt argument å begrunne et obduksjonsønske med.

\section{Anders Svare}

Sykehuset Namsos

Litteratur

1. Svare A. Trenger vi virkelig flere obduksjoner? Tidsskr Nor Legeforen 2010; 130: 756-8.

2. Alfsen $\mathrm{C}$. Ja, vi trenger flere obduksjoner! Tidsskr Nor Legeforen 2010; 130: 1121

Ellingsen CL, Mæhlen J. Heller flere enn færre obduksjoner. Tidsskr Nor Legeforen 2010; 130: 1121 